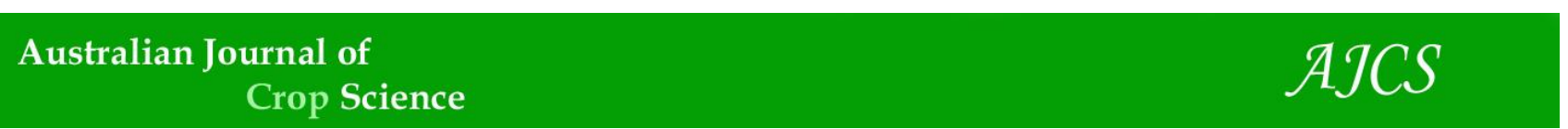

AJCS 14(07):1186-1194 (2020)

ISSN:1835-2707

doi: 10.21475/ajcs.20.14.07.p2698

\title{
Selection of Saccharum spp. rhizobacteria with growth-promoting properties using PCA analysis
}

\author{
Roberta Mendes dos Santos, Everlon Cid Rigobelo*
}

\author{
Post-Graduate Program in Agricultural Microbiology, Faculty of Agrarian and Veterinary Sciences, State \\ University of São Paulo (UNESP), Jaboticabal, Brazil
}

\author{
*Corresponding author: everlon.cid@unesp.br
}

\section{Abstract}

\begin{abstract}
The search for plant growth-promoting rhizobacteria is an ongoing need for the development of new bioinoculants for use in various crops, including sugarcane. Bacterial strains with various plant growth-promoting properties can contribute to sustainable agricultural production. The present study aimed to isolate, characterize and select sugarcane rhizobacteria from six different varieties through principal components analysis. This study selected 167 bacterial strains with the ability to fix nitrogen, produce indolacetic acid, exhibit cellulolytic activity, and solubilize phosphate and potassium were isolated. Of these 167 bacterial strains, seven were selected by principal component analysis and identified as belonging to the genera Staphylococcus, Enterobacter, Bacillus and Achromobacter. Bacillus thuringiensis IP21 presented higher potential for nitrogen fixation and $\mathrm{CaPO}_{4}$ and $\mathrm{AlPO}_{4}$ solubilization and a lower potential for $\mathrm{K}$ solubilization in sugarcane. Enterobacter asburiae IP24 was efficient in indolacetic acid production and $\mathrm{CaPO}_{4}$ and $\mathrm{FePO}_{4}$ solubilization and inefficient for Araxá apatite solubilization.
\end{abstract}

Keywords: Plant Production; plant growth promoting rhizobacteria; sugarcane.

Abbreviations: PGPR_plant growth-promoting rhizobacteria; PCA_principal component analysis; BNF_biological nitrogen fixation; IAA_indolacetic acid.

\section{Introduction}

Although the industrialization of agriculture has brought about major changes in the agricultural production system, with significant increases in productivity, it has also caused serious environmental problems that must be addressed and resolved in the near future. Currently, a major challenge faced by professionals working in the agricultural sector is maintaining productivity with reduced production costs and lower environmental impact. In this context, an alternative is the use of plant growth-promoting rhizobacteria (PGPR) (Pérez-Montaño et al., 2014). This term is used to describe a specific category of microorganisms involved in some rootmicroorganisms-plant interactions that can bring several benefits to plants by promoting plant growth (Zhou et al., 2016).

Plant growth promoting rhizobacteria (PGPR) are widely used in crop production and appeared to be an environmental-friendly approach for improvement in the growth of the plant and soil fertility (Chaturvedi et al., 2020). PGPR produce several compounds, including growth regulation (phytohormones), such as the synthesis of auxins, cytokines, gibberellins, ethylene, and abscisic acid, which help plants in their growth process, such as root extension and cell division. They are also capable of producing siderophores and organic acids, fixing atmospheric nitrogen (N2), solubilizing phosphate and potassium. Therefore increase in nutrient use efficiency, solubilization of insoluble phosphates and potassium, and chelation of micronutrients (Di Salvo et al., 2018; Hayat et al., 2012; Rana et al., 2012;
Roesti et al., 2006; Sheng and He, 2006) which may influence the native soil microbial community due to differential plant growth promotion action. Addition the PGPR can produce antibiotics to suppress pathogenic rhizobacteria. These substances directly and indirectly affect plant metabolism and improve the adaptive capacity of plants to absorb soil nutrients (Grobelak et al., 2015).

Microbial community structure and enzyme activities in the soil are indices for assessment of soil health and quality which are responsible for biogeochemical processes and nutrients transformation (Di Salvo et al., 2018; Hayat et al., 2012). PGPR require to establish and sustain a critical bacterial population in the soil for effective plant growth enhancement and interact with indigenous soil microbes (Kang et al., 2013); therefore, soil microbial ecological studies are necessary (Di Salvo et al., 2018). For commercial exploitation of PGPR as an efficient biofertilizer, it is essential to examine the interaction of native soil microbial community structure and functions for potential ecological impacts. The ecological impact is an important and essential aspect for the influence of PGPR on microbial community study for safe and consistent utilization of PGPR at large scale. The soil inoculation of large extent of exogenous bacteria as PGPR has the probable impact on the indigenous microbes and inoculant may affect them which may results in increase, decrease or no influence on native microbes activities (Bharti et al., 2015; Domenech et al., 2004; Garclá et al., 2004; Li et al., 2018) which warrants the need to be 
study the soil microbial ecology using new analytical and molecular tools.

Although some PGPR promote plant growth, some rhizobacteria-based inoculants may have little or no growthpromoting effect on sugarcane crop, and the selection of new bacterial strains isolated from the own crop with diverse growth-promoting properties may be necessary. With this process of bacterial strain selection, since many strains have diverse plant growth-promoting properties, it is difficult to select the most appropriate bacterial strain as a future bioinoculant (Li et al., 2018)

Given the above, the present study aimed to isolate, characterize and select rhizobacteria in six different varieties of sugarcane carriers of abilities to promote plant growth that could be used as inoculant.

\section{Results}

\section{Screening of bacteria carriers of plant growth abilities}

Sixty bacterial strains were isolated from the rhizospheres of the IAC95-5000 and RB86-7515 varieties in the municipality of Jaboticabal-SP; 62 colonies from the CTC9 and RB85-5156 varieties in the municipality of Frutal-MG and 45 colonies from the IAC91-1099 and CTC4 varieties in the municipality of Pirajuba-MG. A total of 167 bacterial colonies were isolated from the three locations, of which 58 had the capacity to fix N, 20 had the capacity to produce IAA, 53 had cellulolytic activity, and $17,26,44,33,51$ had the capacity to solubilize $\mathrm{K}, \mathrm{CaPO}_{4}, \mathrm{AlPO}_{4}, \mathrm{FePO}_{4}$ and Araxá apatite, respectively (Table 1 ).

The joining of the two principal components allowed a twodimensional ordering of isolates and variables, thus enabling the construction of a biplot graph (Fig. 1). The amount of total information of original variables retained by the two principal components was $50.79 \%, 32.36 \%$ in the first principal component and $18.43 \%$ in the second principal component (Fig. 1).

The order of isolates according to the first two main components allocated isolates into two large groups. The graphical representation allowed for the determination of the variables that most discriminate in the formation of groups I and II. Variables IAA, K, $\mathrm{AlPO}_{4}, \mathrm{FePO}_{4}$ and Araxá apatite solubilization are responsible for the discrimination of group I, located on the left of PC1, exerting great influence on these isolates. Cellulolytic activity and $\mathrm{CaPO}_{4}$ exerted weak influences on group I. Group II did not present any variable with a strong influence on itself; all characteristics showed no effect. Thus, group I was characterized by isolates with the characteristics of being IAA producers and $\mathrm{K}, \mathrm{AlPO}_{4}, \mathrm{FePO}_{4}$ and Araxá apatite solubilizers; therefore, group I was the group of interest and was selected for the next experiments (Fig. 1).

In the municipality of Jaboticabal, 22 bacterial strains were selected after BNF and only 07 were allocated in group I. In the municipality of Pirajuba, 13 of the 20 isolates selected after BNF were allocated in group I. For strains isolated in the municipality of Frutal, no strains were allocated in group I, so these strains were not considered for quantitative characterization. Quantitative analyses were performed on 21 bacterial strains selected after PCA.

Screening the bacteria which presented the better results The first two principal components presented $61.85 \%$ of the total data variance, with PC1 showing $42.39 \%$ of variance and $\mathrm{PC2}, 19.56 \%$. The variables presented were responsible for the formation of three groups of interest. The variables
$\mathrm{AlPO}_{4}, \mathrm{FePO}_{4}$ solubilization, IAA production and cellulolytic activity exerted a strong influence on group I, where isolates IP11 (Enterobacter sp.), IP14 and IP24 (Enterobacter asburiae) were grouped and responsible for their discrimination. $\mathrm{BNF}, \mathrm{CaPO}_{4}$ and Araxá apatite solubilization were responsible for the distinction of group II, which included isolates IJ8 (Staphylococcus saprophyticus), IP17 (Bacillus anthracis) and IP21 (Bacillus thuringiensis). Group III was influenced by only one variable, $\mathrm{K}$ solubilization, and the isolate IP23 was grouped in group III (Achromobacter spanius) (Fig. 2).

Of isolates selected by PCA, six were from Pirajuba (IP) and only one was from Jaboticabal (IJ) (Fig. 2). For isolates that did not group, their molecular identification was not performed. Therefore, molecular identification was performed on seven bacterial strains.

For IAA production, the largest producers were IP14 and IP24 (E. asburiae), with 56.68 and $56.21 \mu \mathrm{g}$ of IAA mL ${ }^{-1}$, respectively. For cellulolytic activity and $\mathrm{K}$ solubilization, isolate IP23 (A. spanius) stood out, producing $0.61 \mathrm{U} \mathrm{mL}^{-1}$ and $17.23 \mathrm{mg} \mathrm{K} \mathrm{mL}^{-1}$, respectively. For BNF, isolates IP21 (B. thuringiensis) and IJ8 ( $S$. saprophyticus) were the major fixators, with 108.07 and $105.61 \mu \mathrm{g} \mathrm{N} \mathrm{mL}^{-1}$, respectively (Fig. 3).

For $\mathrm{CaPO}_{4}$ and $\mathrm{AlPO}_{4}$ solubilization, isolate IP21 (B. thuringiensis) stood out, solubilizing 481.00 and $39.33 \mathrm{mg}$ of $\mathrm{P} \mathrm{mL}$, while isolate IP17 (B. anthracis) was the best for Araxá apatite solubilization and IP14 stood out in $\mathrm{FePO}_{4}$ solubilization, with 622.99 and $105.66 \mathrm{mg}$ of $\mathrm{P} \mathrm{mL}^{-1}$, respectively (Fig. 3).

\section{Molecular identification of bacterial strains}

The selected strains that formed the three main groups according to PCA were identified using PCR amplification of the $16 \mathrm{~S}$ rRNA gene. All isolates were identified by the $16 \mathrm{~S}$ rDNA sequence and showed more than $95 \%$ homology with other sequences deposited at GenBank (Table 2).

Isolate IJ8 was homologous to sequences of Staphylococcus saprophyticus and showed more than $99 \%$ identity with two sequences. The identification of isolate IP11 was performed at the genus level, demonstrating $99.85 \%$ homology with two Enterobacter sequences. Isolate IP14 showed over 95\% homology with the genus Enterobacter. Isolate IP17 was identified as Bacillus anthracis based on $99.88 \%$ sequence identity. The identification of isolate IP21 was performed according to homology with sequences of Bacillus thuringiensis, with identity above 99.5\%. Isolate IP23 was identified from homology with sequences of Achromobacter spanius, with $99.29 \%$ sequence homology. Finally, isolate IP24 was homologous with Enterobacter asburiae sequences with $99.84 \%$ identity.

A phylogenetic tree was constructed to demonstrate similarity between bacterial strain sequences of the present study and sequences deposited in GenBank, in addition to demonstrating similarity to each other (Fig. 4).

\section{Discussion}

The present study used PCA to determine the statistical correlation between isolates and growth promotion characteristics. Figure 1 shows that group I was characterized by isolates that produce IAA and solubilize $\mathrm{K}$, $\mathrm{AlPO}_{4}, \mathrm{FePO}_{4}$, and Araxá apatite. Group II has no growthpromoting variables of interest (Fig. 1). 
Sugarcane is a plant, and a large variety of bacteria have been isolated, characterized and identified in its rhizosphere. Through PCA, the present work was able to isolate for the first time $S$. saprophyticus, $E$. asburiae, $A$. spanius and $B$. anthracis strains in the sugarcane rhizosphere. In addition, of the seven strains identified, there was no repetition of species; therefore, the strains were seven distinct species.

The S. saprophyticus IJ8 strain stood out for BNF (105.61 $\mu \mathrm{g}$ of $\left.\mathrm{N} \mathrm{mL}^{-1}\right)$ and $\mathrm{CaPO}_{4}\left(4.67 \mathrm{mg} \mathrm{P} \mathrm{mL}^{-1}\right)$ and Araxá apatite solubilization (444.00 mg $\mathrm{P} \mathrm{mL}^{-1}$ ) (Fig. 3), important characteristics to be considered for PGPR. Strains that exhibit efficient $\mathrm{N}$ fixation and $\mathrm{P}$ solubilization tend to be good inoculants because $\mathrm{N}$-fixing PGPR inoculation in crops revitalizes plant growth, promoting activities, the management of diseases and low nitrogen levels in agricultural soils (Damam et al., 2016). Phosphorus is the second most essential nutrient demanded by plants, and in adequate amounts for optimal growth, it plays an important role in almost all major metabolic processes, including energy transfer, signal transduction, respiration, macromolecular biosynthesis and photosynthesis (Anand et al., 2016).

Members of the genus Staphylococcus are well known human pathogens, but some species have been isolated from soil (Zamil et al., 2010), wild rice (Oryza rufipogon) (Sarathambal et al., 2015), grape (Barata et al., 2012), and oil-contaminated samples (Silva et al., 2015), suggesting their opportunistic mode of existence and demonstrating wide variation in the environment where they can be found. Some authors searching for new growth-promoting isolates have been able to characterize and identify S. saprophyticus isolates.

Isolates IP11 and IP14 had high similarity with sequences of Enterobacter sp. (Table 2), but when the phylogenetic tree was constructed, IP14 did not group with GenBank database sequences, indicating that this isolate could represent some species not yet identified (Figure 4). Elo et al. (2000) analyzed 165 rDNA sequences from bacteria isolated from the humus layer and found unknown Paenibacillus species. Similarly, Beneduzi et al. (2013) found rhizobacteria isolated from sugarcane, and some isolates had no similarity to any sequence in the available databases.

Enterobacter sp. is a bacterium that has been found and classified only at the genus level by several researchers searching for PGPR (Sajjad Mirza et al., 2001). Waghmare et al. (2018) demonstrated the potential of Enterobacter sp. as a cellulolytic bacterium. Patel et al. (2019) found a phosphorus-solubilizing and IAA-producing strain, as well as in the present study, where Enterobacter sp. IP11 produced $53.32 \mu \mathrm{g}$ of IAA mL ${ }^{-1}$ (Fig. 3). Enterobacter sp. has also been isolated from chromium-contaminated soils suggesting that it is resistant to chromium and promoting the growth of tomato plants under $\mathrm{Cr}$ stress conditions (Gupta et al., 2019).

E. asburiae is also known to be an opportunistic pathogen, but its strains have been isolated from a wide variety of environments, including rhizosphere and agricultural soil (Gyaneshwar et al., 1999), cotton (Quadt-Hallmann and Kloepper, 1996), Arabidopsis thaliana (Cooley et al., 2003), mustard (Ahemad and Kibret, 2014), tobacco (Ahemad and Khan, 2010; Zhang and Kong, 2014), and sugarcane roots (Kruasuwan and Thamchaipenet, 2016).

asburiae IP24 could be used as a growth promoter, standing out in $\mathrm{FePO}_{4}, \mathrm{CaPO}_{4}$ solubilization (79.00 and $452.67 \mathrm{mg} \mathrm{P}$ $\mathrm{mL}^{-}{ }^{1}$, respectively) and IAA production $(56.21 \mu \mathrm{g} \mathrm{IAA} \mathrm{mL}$
(Figure 3). In the search for growth-promoting sugarcane endophytes, Kruasuwan and Thamchaipenet (2016) isolated an $E$. asburiae strain, but this strain was negative for $P$ solubilization, Ahemad and Khan (2010) when characterizing E. asburiae, they also observed their growth-promoting characteristics; the strain produced $32 \mu \mathrm{g}$ of IAA $\mathrm{mL}^{-1}$, while the strain of this study produced $56.21 \mu \mathrm{g}$ of IAA $\mathrm{mL}^{-1}$, almost twice the value obtained by the authors. Because nutritional elements are absorbed from soil by roots, good root growth is considered a prerequisite for increased plant growth, and IAA is one of the most important plant hormones produced by bacteria, improving the protection level against adverse external effects and increasing the coordination of various cell defense systems (Spaepen and Vanderleyden, 2011).

A. spanius IP23 stood out for $\mathrm{K}$ solubilization $\left(17.3 \mathrm{mg} \mathrm{K}^{-1}\right.$ ) and cellulolytic activity (0.61 $\mathrm{U} \mathrm{mL}^{-1}$ ) (Fig. 3). Previously, $A$. spanius was found in medicinal plants, being positive for cellulolytic activity, but with low IAA production (4.2 $\mu \mathrm{g}$ IAA $\mathrm{mL}^{-1}$ ) (Egamberdieva et al., 2017); this result was similar to the present study, where the $A$. spanius isolate produced the lowest IAA concentration $\left(6.30 \mu \mathrm{g}\right.$ of IAA $\left.\mathrm{mL}^{-1}\right)$. A. spanius has also been found in soil (Castanheira et al., 2014) and characterized for growth promotion in Phragmites australis (Soares et al., 2016) and ryegrass (Lolium multiflorum) (Castanheira et al., 2014).

When constructing the phylogenetic tree, isolate IP21 had a low bootstrap value (Figure 4), which may be explained by the genetic similarity of $B$. anthracis and $B$. thuringiensis. These species are very close to each other, and some studies suggest that $B$. anthracis is a narrow group of strains that show a high degree of genetic similarity and that inclusions of bioinsecticide crystals are the only distinguishing feature of B. thuringiensis (Jensen et al., 2003). Sometimes, phylogenetic analysis based on the 16S rRNA gene sequence is not able to differentiate $B$. anthracis and $B$. thuringiensis (Jamil, 2015; Tchuisseu Tchakounté et al., 2018).

Despite being known as an animal and human pathogen, $B$. anthracis strains were previously found in the search for tomato rhizosphere growth promoters, where they were positive for $\mathrm{N}$ fixation and IAA production $( \pm 6.45 \mu \mathrm{g}$ IAA mL $\left.{ }^{1}\right)$ (Tian et al., 2017). The $B$. anthracis IP17 strain of the present study produced $45.34 \mu \mathrm{g}$ IAA mL $\mathrm{m}^{-1}$ and stood out for Araxá apatite solubilization, $623.00 \mathrm{mg} \mathrm{P} \mathrm{mL}^{-1}$ (Figure 3). Other authors have managed to isolate $B$. anthracis from Phragmites australis (L.) rhizosphere (Chaturvedi et al., 2006) and atrazine-contaminated soils (El-Bestawy et al., 2013), but these authors did not observe whether these strains presented growth-promoting properties. No reports of $B$. anthracis associated with sugarcane were found in the literature regarding rhizospheric or endophytic bacteria. The isolate $B$. anthracis IP17 could be cited as the first report found in the sugarcane rhizosphere.

$B$. thuringiensis is well known for its specific bioactivity, due to its capacity to produce crystals, which are formed by polypeptides known as Cry proteins. These proteins have entomopathogenic properties for insects of the orders Lepidoptera, Diptera, Coleoptera, Hymenoptera, and Homoptera, in addition to nematodes, protozoa and mites (Jensen et al., 2003). In sugarcane, B. thuringiensis has been intensively studied for the control of borer (Diatraea saccharalis) (Huang et al., 2008; Wu et al., 2009), but there are few studies that directly relate this species as a growth promoter in sugarcane and other crops. 
Table 1. Total number of bacteria strains with BNF, IAA production, cellulolytic activity (CA), $\mathrm{K}, \mathrm{CaPO}_{4}, \mathrm{AlPO}_{4}, \mathrm{FePO}_{4}$, and Araxá apatite solubilization properties isolated from the IAC95-5000, RB86-7515, CTC9, RB75-5156, IAC91-1099, CTC4 varieties in the municipalities of Jaboticabal, Frutal and Pirajuba.

\begin{tabular}{|c|c|c|c|c|c|c|}
\hline Municipality & Jabotic & & Frutal & & Pirajuba & \\
\hline Variety & $\begin{array}{l}\text { IAC95- } \\
5000\end{array}$ & RB86-7515 & СТC9 & RB75-5156 & IAC91-1099 & CTC4 \\
\hline Strain code & IJ & RJ & $\mathrm{CF}$ & $\mathrm{RF}$ & IP & $\mathrm{CP}$ \\
\hline Total strains & 33 & 27 & 29 & 33 & 24 & 21 \\
\hline BNF & 7 & 15 & 6 & 9 & 12 & 8 \\
\hline IAA & 1 & 7 & 1 & 0 & 7 & 4 \\
\hline CA & 7 & 14 & 5 & 6 & 12 & 8 \\
\hline \multicolumn{7}{|l|}{ Solubilization: } \\
\hline K & 2 & 3 & 0 & 0 & 8 & 3 \\
\hline $\mathrm{CaPO}_{4}$ & 5 & 7 & 2 & 4 & 4 & 3 \\
\hline $\mathrm{AlPO}_{4}$ & 2 & 11 & 4 & 5 & 12 & 8 \\
\hline $\mathrm{FePO}_{4}$ & 3 & 7 & 3 & 3 & 11 & 5 \\
\hline Apatite & 7 & 11 & 6 & 6 & 12 & 8 \\
\hline
\end{tabular}

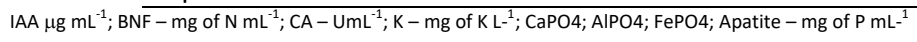

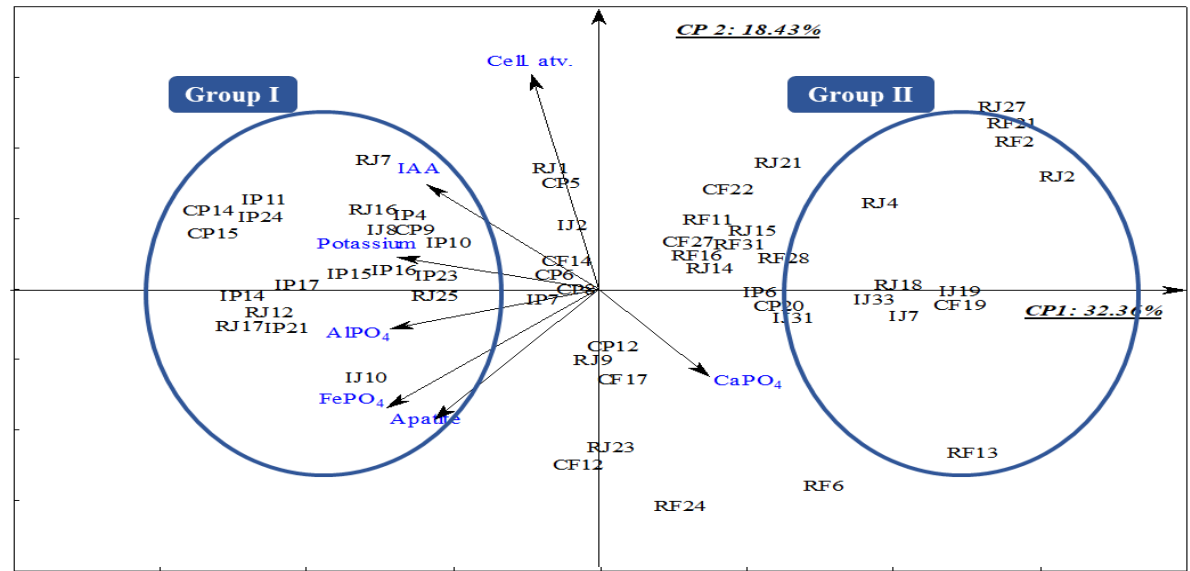

Fig 1. Dispersion (biplot graph) of qualitatively analyzed growth-promoting characteristics, namely cellulolytic activity (Cell.act), IAA production (IAA), $\mathrm{K}, \mathrm{AlPO}_{4}, \mathrm{FePO} 4, \mathrm{CaPO}_{4}$ and Araxá apatite solubilization. *Strain code: First letter: initial of the variety used for isolation (IAC95-5000, RB86-7515, CTC 9, RB75-5156., IAC91-1099 and CTC4). Second letter: initial of the municipality where the isolation was performed (Jaboticabal, Frutal and Pirajuba). Numeric code: number assigned to the strain according to the sequence in which it was isolated.

Table 2. Identification of sugarcane rhizospheric bacteria using NCBI BLAST-N of 16S rRNA gene sequences.

\begin{tabular}{lll}
\hline Isolate & Species identification & Identity (\%) \\
\hline \multirow{2}{*}{ IJ8 } & Staphylococcus saprophyticus NR_114090.1 & 99.76 \\
& Staphylococcus saprophyticus MG694483.1 & 100.00 \\
\hline \multirow{2}{*}{ P11 } & Enterobacter sp. KR558701.1 & 99.85 \\
& Enterobacter sp. HM748078.1 & 99.85 \\
\hline \multirow{2}{*}{ P14 } & Enterobacter sp. KR558701.1 & 96.34 \\
& Enterobacter sp. HM748078.1 & 96.34 \\
\hline \multirow{2}{*}{ P17 } & Bacillus anthracis MK575034.1 & 99.88 \\
& Bacillus anthracis AF290553. & 99.88 \\
\hline \multirow{2}{*}{ P21 } & Bacillus thuringiensis NR_112780.1 & 99.79 \\
& Bacillus thuringiensis KT159186.1 & 99.68 \\
\hline IP23 & Achromobacter spanius MN007235.1 & 99.29 \\
& Achromobacter spanius NR_025686.1 & 99.29 \\
\hline IP24 & Enterobacter asburiae MG571735.1 & 99.84 \\
& Enterobacter asburiae KY316493.1 & 99.84 \\
\hline \multirow{2}{*}{ * Query cov }
\end{tabular}

* Query cov., 100\%; and E-value, 0.0 , for all sequence 


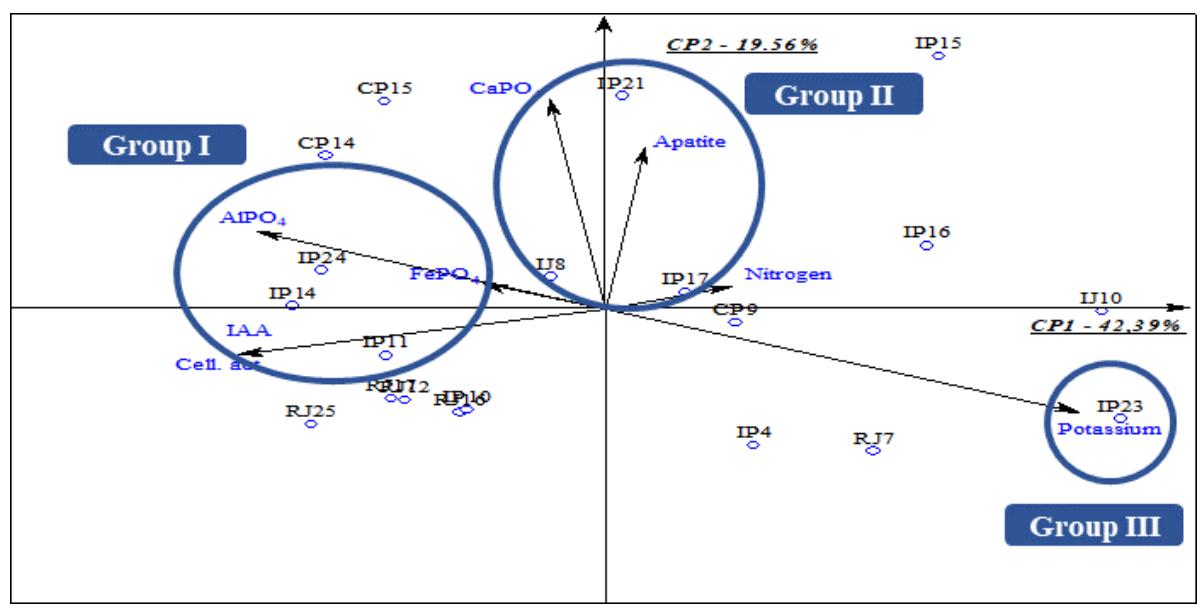

Fig 2. Dispersion (biplot graph) of the quantitatively analyzed growth-promoting characteristics, namely, BNF quantification, cellulolytic activity (Cell.Act), IAA production, $\mathrm{K}, \mathrm{AlPO}_{4}, \mathrm{FePO}_{4}, \mathrm{CaPO}_{4}$ and Araxá apatite solubilization.
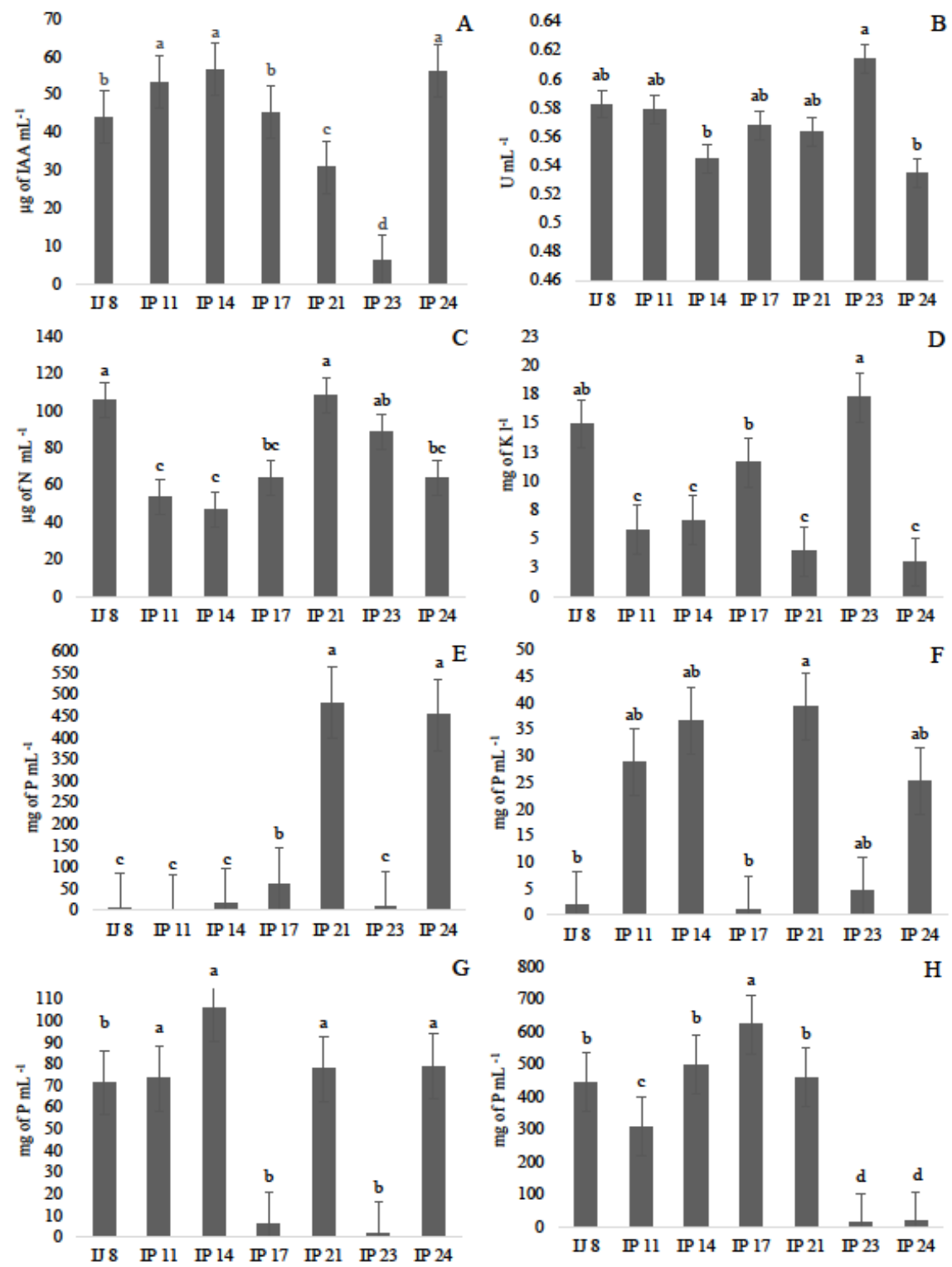

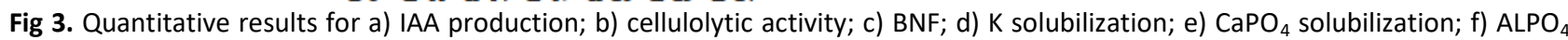
solubilization; g) $\mathrm{FePO}_{4}$ solubilization and; h) Araxá apatite solubilization. Means followed by the same letters do not differ according to the Tukey test at $5 \%$ probability. ${ }^{*}$ S. saprophyticus IJ8, Enterobacter sp. IP11, B. anthracis IP17, B. thuringiensis IP21, A. spanius IP23, E. asburiae IP24. 


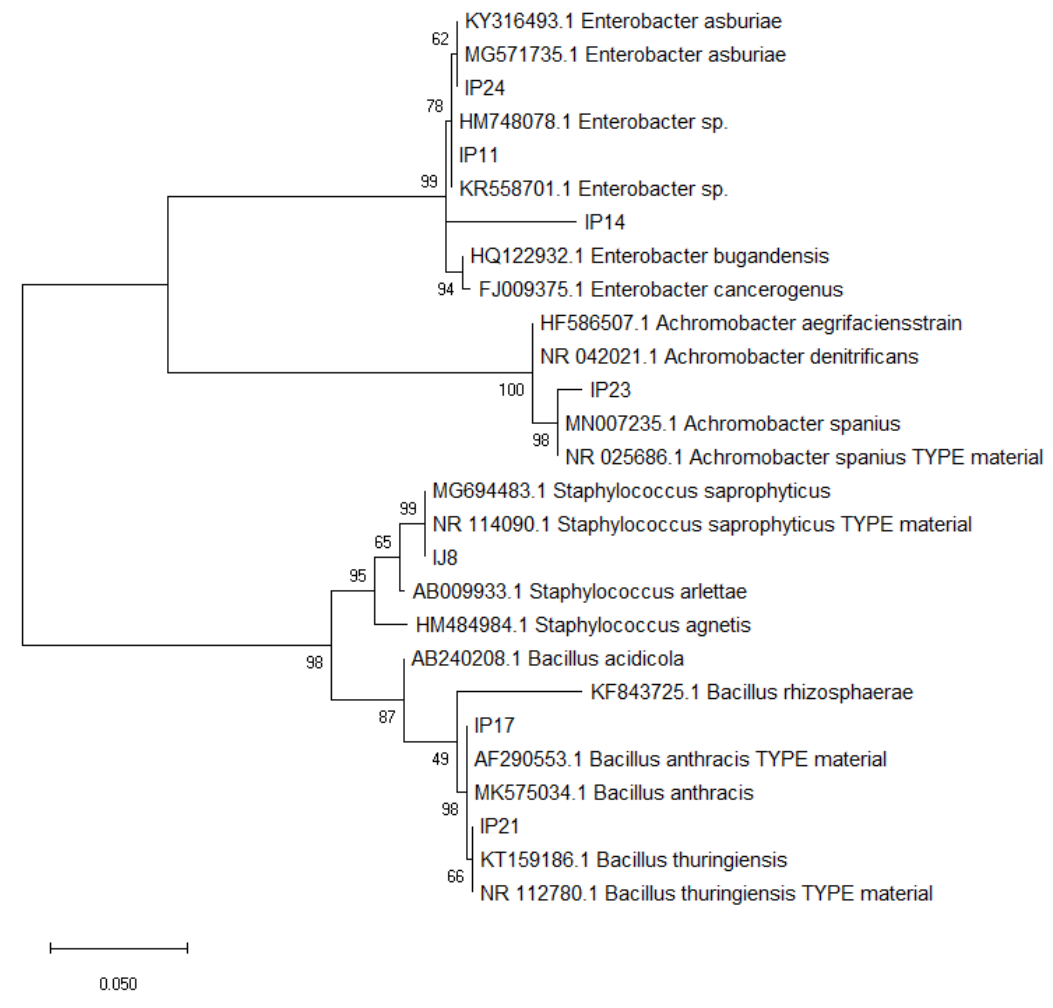

Fig 4. Phylogenetic analysis of the $16 \mathrm{~S}$ ribosomal region of the seven strains isolated and grouped into the three groups by PCA (Fig. 2). The phylogenetic tree was constructed based on the maximum probability with the evolutionary method and distances calculated according to the Kimura-2 parameter. Boot values are presented as a percentage for 1000 bootstraps. Numeric codes before species names refer to the GenBank (NCBI) accession number

B. thuringiensis strains that were positive for $\mathrm{P}$ solubilization and IAA production were isolated from Kobresia capillifolia (de Freitas et al., 1997; Ying et al., 2016). The B. thuringiensis IP21 strain was a great solubilizer of the phosphate sources tested $\left(481.00,39.33,77.66,457.66 \mathrm{mg} \mathrm{P} \mathrm{mL}^{-1}\right.$ for $\mathrm{CaPO}_{4}$, $\mathrm{FePO}_{4}, \mathrm{AlPO}_{4}$ and Araxá apatite, respectively), in addition to being the strain that fixed the largest amount of $\mathrm{N}, 108.07$ $\mu \mathrm{g} \mathrm{N} \mathrm{mL} L^{-1}$. B. thuringiensis has also been isolated from Pinus Sylvestris (Babu et al., 2013).

\section{Materials and methods}

\section{Rhizospheric soil}

Sugarcane rhizospheric soil samples were collected in the municipality of Jaboticabal - SP (210 15 ' 17 "S and 48 19' 20" W) and included the IAC95-5000 and RB86-7515 varieties. Collection was also performed in the municipality of Pirajuba - MG (19 54 ' $32^{\prime \prime}$ S and $48^{\circ} 42^{\prime} 9$ 'W), the IAC911099 and CTC4 varieties, and in the municipality of Frutal MG (20 01' 29 " S and 48 56 '26 "W), the CTC9 and RB855156 varieties. Soil samples were collected and transported to the Laboratory of Agricultural Microbiology, UNESP, Campus of Jaboticabal. Field permits were not required for this research. In Jaboticabal, the land we sampled belongs to our institution (State University of São Paulo (UNESP).

Bacteria from rhizospheric soil samples were isolated by serial dilution (Wollum, 1982); (Vieira and Nahas, 2005). After incubation, bacterial colonies were picked, placed into SMA-containing test tubes and refrigerated for later use.

\section{Screening of isolates}

All strains were tested for biological nitrogen fixation capacity (BNF) in plates, and strains with this characteristic were then tested for phosphate solubilization $\left(\mathrm{CaPO}_{4}, \mathrm{AlPO}_{4}\right.$, $\mathrm{FePO}_{4}$ and Araxá apatite), potassium solubilization (Ekosil ${ }^{\circledR}$ ), indolacetic acid (IAA) production and cellulolytic activity. Through PCA, bacterial strains that presented the best results for the parameters mentioned above were selected. For the quantification of plant growth promotion properties, all strains were grown for $24 \mathrm{~h}$ in nutrient broth at a concentration of $1 \times 10^{8}$ colony forming units (CFU). Analyses were performed in triplicate, and media without the presence of bacteria were used as controls.

\section{Biological Nitrogen Fixation (BNF)}

Nitrogen fixation capacity was evaluated according to (Dobereiner et al. (1996) and (Tedesco et al., 1995).

\section{Phosphate solubilization}

Phosphate solubilization based on bacterial culture was measured according to (Berraquero et al., 1976). Four phosphate sources were tested: $\mathrm{CaPO}_{4}$, Araxá apatite $\left(3 \mathrm{Ca}_{3}\left(\mathrm{PO}_{4}\right)_{2} \mathrm{CaF}_{2}\right), \mathrm{AlPO}_{4}$, and $\mathrm{FePO}_{4}$ in the amounts of $5 \mathrm{~g}, 5$ $\mathrm{g}, 3.5 \mathrm{~g}$, and $4.33 \mathrm{~g}$, respectively, per $1 \mathrm{~L}$ of medium (Silva Filho and Vidor, 2000)

\section{Potassium Solubilization}

Potassium solubilization was measured using Ekosil ${ }^{\circledR}$ fertilizer, which is an alternative source of $\mathrm{K}$ produced from 
rock of volcanic origin called phonolite, containing $8 \%$ soluble $\mathrm{K}_{2} \mathrm{O}$ (Yoorin, 2018).

\section{IAA production}

IAA production was measured according to Sarwar and Kremer (1995).

\section{Cellulolytic activity}

The cellulolytic activity was measured by (Ramachandra et al., 1987) and (Ghose, 1987).

\section{Data analysis}

Data were initially submitted to the PCA multivariate statistical method to group bacterial strains, which was performed after standardization of variables in which each variable had a mean of 0 and a variance of 1 . A biplot was constructed for the first two principal components with isolates and growing promotion characteristics. STATISTICA software version 7.0 was used for processing statistical analyses (Statsoft, 2014) .

Quantitative data were also subjected to analysis of variance (F-test), comparing treatment means by the Tukey test at $5 \%$ probability using AgroEstat software version 1.0 (Barbosa and Maldonado, 2010).

\section{Molecular identification of bacterial strains}

Strains that showed the best results consistent with previously described properties were identified following the Quick-DNA Universal extraction kit protocol (ZymoResearch cat, No. D4068 and D4069) (Sambrook and Fritsch, 1989).

For identification, PCR products were purified using the Wizard ${ }^{\circledR}$ SV Gel and PCR Clean-up System Kit and sequenced using universal primers. Sequences were edited using the Biological Sequence Alignment Editor - BioEdit (Hall, 1999); the consensus sequence was obtained using the BLAST ${ }^{\circledR}$ tool (Altschul et al., 1990) and compared with the National Center for Biotechnology Information (NCBI - GenBank) database. The resulting phylogenetic trees were constructed using MEGA $7^{\circledR}$ software (Tamura et al., 2011).

\section{Conclusion}

The PCA was a great strategy and a useful tool to select rhizobacteria strains from sugarcane, such as $S$. saprophyticus, E. asburiae, $A$. spanius e $B$. anthracis. These bacteria showed similar behavior and expressed important characteristics related to plant growth-promoting. However, more studies are needed to verify if these selected strains will show positive aspects on sugarcane plants, including an increase of yield.

\section{Acknowledgements}

The authors are grateful to CAPES for providing scholarships and the post-graduate program in Agricultural Microbiology, UNESP - FCAV.

\section{References}

Ahemad M, Khan M S (2010) Plant growth promoting activities of phosphate-solubilizing Enterobacter asburiae as influenced by fungicides. Eurasia J Biosci. 88-95.

Ahemad M, Kibret M (2014) Mechanisms and applications of plant growth promoting rhizobacteria: Current perspective. JKSUES. 26:1-20).

Altschul SF, Gish W, Miller W, Myers EW Lipman DJ (1990) Basic local alignment search tool. J. Mol. Biol 3:403-410.

Anand K, Kumari B, Mallick MA (2016) Phosphate solubilizing microbes: an effective and alternative approach as biofertilizers. J Pharm Pharm Sci. 8:37-4.

Babu AG, Kim JD, Oh BT (2013) Enhancement of heavy metal phytoremediation by Alnus firma with endophytic Bacillus thuringiensis GDB-1. J Hazard Mater. 250:477-483.

Barata A, Malfeito-Ferreira M, Loureiro V (2012) Changes in sour rotten grape berry microbiota during ripening and wine fermentation. Int J Food Microbiol. 3:152-161.

Barbosa JC, Maldonado JW (2010) AgroEstat: sistema para análises estatísticas de ensaios agronômicos. Versão 1.0.

Beneduzi A, Moreira F, Costa PB, Vargas LK, Lisboa BB, Favreto R, Baldani JI, Passaglia, L MP (2013) Diversity and plant growth promoting evaluation abilities of bacteria isolated from sugarcane cultivated in the South of Brazil. Appl Soil Eco. 63:94-104.

Berraquero FR, Baya B, Cormenzana AR (1976) Establecimiento de índices para el estudio de la solubilización de fosfatos por bacterias del suelo. Ciencia Del Suelo. 17:399-406.

Bharti N, Barnawal D, Maji D \& Kalra A (2015) Halotolerant PGPRs prevent major shifts in indigenous microbial community structure under salinity stress. Microb Ecol. 70(1):196-208.

Castanheira N, Dourado AC, Alves PI, Cortés-Pallero AM, Delgado-Rodríguez Al, Prazeres Â, Borges N, Sánchez C, Barreto Crespo MT, Fareleira P (2014) Annual ryegrassassociated bacteria with potential for plant growth promotion. Microbiol Res. 169:768-779.

Cavalcante VA, Dobereiner J (1988) A new acid-tolerant nitrogen-fixing bacterium associated with sugarcane. Plant Soil. 108:23-31.

Chaturvedi S, Chandra R, Rai V (2006) Isolation and characterization of Phragmites australis (L.) rhizosphere bacteria from contaminated site for bioremediation of colored distillery effluent. Ecol Eng. 27:202-207.

Chaudhary DR, Rathore AP \& Sharma S (2020) Effect of halotolerant plant growth promoting rhizobacteria inoculation on soil microbial community structure and nutrients. Appl Soil Ecol 150:103461.

Cooley MB, Miller WG, Mandrell RE (2003) Colonization of Arabidopsis thaliana with Salmonella enterica and enterohemorrhagic Escherichia coli 0157: $\mathrm{H7}$ and competition by Enterobacter asburiae. Appl Environ Microbiol. 69:4915-4926.

Damam M, Kaloori K, Gaddam B, Kausar R (2016) Plant growth promoting substances (phytohormones) produced by rhizobacterial strains isolated from the rhizosphere of medicinal plants. Int J Pharm Sci Rev Res. 37:130-136.

Di Salvo LP, Cellucci GC, Carlino ME, de Salamone IEG (2018) Plant growth-promoting rhizobacteria inoculation and nitrogen fertilization increase maize (Zea mays L.) grain yield and modified rhizosphere microbial communities. Appl Soil Ecol 126:113-120.

Domenech J, Ramos-Solano B, Probanza A, Lucas-García JA, Colón JJ \& Gutiérrez-Mañero FJ (2004) Bacillus spp. and Pisolithus tinctorius effects on Quercus ilex ssp. ballota: a study on tree growth, rhizosphere community structure 
and mycorrhizal infection. Forest Ecol Manag. 194(13):293-303.

De Freitas JR, Banerjee MR, Germida JJ (1997) Phosphatesolubilizing rhizobacteria enhance the growth and yield but not phosphorus uptake of canola (Brassica napus L.). Biol Fertil Soils. 24:358-364.

Silva DDSP, de Lima Cavalcanti D, de Melo EJV, dos Santos PNF, da Luz ELP, de Gusmão NB, de Queiroz MDFV (2015) Bio-removal of diesel oil through a microbial consortium isolated from a polluted environment. Int Biodeter Biodegr. 97:85-89.

Dobereiner J, Baldani VLD, Baldani JI (1996) Como isolar e identificar bacterias diazotroficas de plantas naoleguminosas. Embrapa-SPI.

Egamberdieva D, Wirth S, Behrendt U, Ahmad P, Berg G (2017) Antimicrobial activity of medicinal plants correlates with the proportion of antagonistic endophytes. Front Microbiol. 8:199.

El-Bestawy E, Sabir J, Mansy AH, Zabermawi N (2013) Isolation, identification and acclimatization of Atrazineresistant soil bacteria. Ann Agric Sci. 58:119-130.

Elo S, Maunuksela L, Salkinoja-Salonen M, Smolander A, Haahtela K (2006) Humus bacteria of Norway spruce stands: plant growth promoting properties and birch, red fescue and alder colonizing capacity. FEMS Microbiol Ecol. 31:143-152.

García JAL, Domenech J, Santamaría C, Camacho Ma, Daza A \& Mañero FJG (2004) Growth of forest plants (pine and holm-oak) inoculated with rhizobacteria: relationship with microbial community structure and biological activity of its rhizosphere. Environ Exp Bot. 52(3):239-251

Malavolta E, Vitti GC, Oliveira SAD (1989) Avaliação do estado nutricional das plantas: princípios e aplicações.

Ghose TK (1987) Measurement of cellulase activities. Pure Appl Chem. 59:257-268.

Grobelak A, Napora A, Kacprzak M (2015) Using plant growth-promoting rhizobacteria (PGPR) to improve plant growth. Ecol Eng. 84:22-28.

Gupta N, Skinner KA, Khan S, Edirisinghe JN, Henry CS (2019) Draft genome sequence of Enterobacter sp. strain A8, a carbazole-degrading bacterium. Microbiol Resour Announc. 8:e00301-19

Gyaneshwar P, Parekh L, Archana G, Poole P, Collins M, Hutson R, Kumar GN (1999) Involvement of a phosphate starvation inducible glucose dehydrogenase in soil phosphate solubilization by Enterobacter asburiae. FEMS Microbiol Eco. 171:223-229.

Haidar B, Ferdous M, Fatema B, Ferdous AS, Islam MR, Khan $H$ (2018) Population diversity of bacterial endophytes from jute (Corchorus olitorius) and evaluation of their potential role as bioinoculants. Microbiol Res. 208:43-53.

Hall TA (1999) BioEdit: a user-friendly biological sequence alignment editor and analysis program for Windows 95/98/NT. Nucleic Acids Symp Ser. 41:95-98

Hayat R, Ahmed I \& Sheirdil RA (2012) An overview of plant growth promoting rhizobacteria (PGPR) for sustainable agriculture crop production for agricultural improvement. Springer, p 557-579

Hu X, Chen J, Guo J (2006) Two phosphate- and potassiumsolubilizing bacteria isolated from Tianmu Mountain, Zhejiang, China. World J Microbiol Biotechnol. 22:983-990.

Huang $F$, Leonard R, Moore S, Yue B, Parker R, Reagan T, Stout M, Cook D, Akbar W, Chilcutt C, White W, Lee D, Biles S (2008) Geographical susceptibility of Louisiana and Texas populations of the sugarcane borer, Diatraea saccharalis (F.) (Lepidoptera: Crambidae) to Bacillus thuringiensis Cry1Ab protein. Crop Prot. 2:799-806.

Sambrook J, Fritsch EF, Maniatis T (1989) Molecular cloning: a laboratory manual (Ed. 2). Cold spring harbor laboratory press.

Jamil M (2015) Plant Growth promoting rhizobacteria: An alternate way to improve yield and quality of wheat (Triticum aestivum). Proc Natl Acad Sci. 17:1.

Jensen GB, Hansen BM, Eilenberg J, cMahillon J (2003) The hidden lifestyles of Bacillus cereus and relatives. Environ Microbiol. 5:631-640.

Kang $Y$, Shen M, Wang H, Zhao Q (2013) A possible mechanism of action of plant growth-promoting rhizobacteria (PGPR) strain Bacillus pumilus WP8 via regulation of soil bacterial community structure. J Gen Appl Microbiol 59(4):267-277

Kruasuwan W, Thamchaipenet A (2016) Diversity of culturable plant growth-promoting bacterial endophytes associated with sugarcane roots and their effect of growth by co-inoculation of diazotrophs and actinomycetes. J Plant Growth Regul. 35:1074-1087.

Kuss AV, Kuss VV, Lovato T, Flôres ML (2007) Fixação de nitrogênio e produção de ácido indolacético in vitro por bactérias diazotróficas endofíticas. Pesq agropec bras. 42:1459-1465.

Li L, Ma J, Ibekwe AM, Wang Q, Yang C-H (2018) Influence of Bacillus subtilis $\mathrm{B} 068150$ on cucumber rhizosphere microbial composition as a plant protective agent. Plant and Soil 429(1-2):519-531

Marcano IE, Díaz-Alcántara CA, Urbano B, González-Andrés F (2016) Assessment of bacterial populations associated with banana tree roots and development of successful plant probiotics for banana crop. Soil Biol Biochem. 99:120.

Tedesco MJ, Gianello C, Bissani CA, Bohnen H, Volkweiss SJ (1995) Análises de solo, plantas e outros materiais 174:Porto Alegre: Ufrgs.

Nautiyal CS (1999) An efficient microbiological growth medium for screening phosphate solubilizing microorganisms. FEMS Microbiol Eco. 170:265-270.

Patel P, Shah R, Joshi B, Ramar K, Natarajan A (2019) Molecular identification and biocontrol activity of sugarcane rhizosphere bacteria against red rot pathogen Colletotrichum falcatum. Biotechnol Rep. 21:e00317

Pérez-Montaño F, Alías-Villegas C, Bellogín RA, Del Cerro P, Espuny, MR, Jiménez-Guerrero I, López-Baena FJ, Ollero FJ, Cubo T (2014) Plant growth promotion in cereal and leguminous agricultural important plants: From microorganism capacities to crop production. Microbiol Res. 169:325-336.

Quadt-Hallmann A, Kloepper JW (1996) Immunological detection and localization of the cotton endophyte Enterobacter asburiae JM22 in different plant species. Can J Microbiol. 42:1144-1154.

Ramachandra M, Crawford DL, Pometto AL (1987) Extracellular Enzyme activities during lignocellulose degradation by Streptomyces spp.: a comparative study of wild-type and genetically manipulated strains. Appl Environ Microbiol. 53:2754-2760.

Rana A, Saharan B, Joshi M, Prasanna R, Kumar K \& Nain L (2011) Identification of multi-trait PGPR isolates and evaluating their potential as inoculants for wheat. Ann Microbiol. 61(4):893-900. 
Roesti D, Gaur R, Johri B, Imfeld G, Sharma S, Kawaljeet K \& Aragno M (2006) Plant growth stage, fertiliser management and bio-inoculation of arbuscular mycorrhizal fungi and plant growth promoting rhizobacteria affect the rhizobacterial community structure in rain-fed wheat fields. Soil Biol Biochem. 38(5):1111-1120

Sajjad Mirza M, Ahmad W, Latif F, Haurat J, Bally R, Normand $P$, Malik KA (2001) Isolation, partial characterization, and the effect of plant growth-promoting bacteria (PGPB) on micro-propagated sugarcane in vitro. Plant soil. 237:4754.

Sarathambal C, Ilamurugu K, Balachandar D, Chinnadurai C, Gharde Y (2015) Characterization and crop production efficiency of diazotrophic isolates from the rhizosphere of semi-arid tropical grasses of India. Appl Soil Ecol. 87:1-10.

Sheng XF \& He LY (2006) Solubilization of potassium-bearing minerals by a wild-type strain of Bacillus edaphicus and its mutants and increased potassium uptake by wheat. Can J Microbiol. 52(1):66-72.

Sarwar M, Kremer RJ (1995) Determination of bacterially derived auxins using a microplate method. Lett Appl Microbio. 20: 282-285.

Silva Filho GN, Vidor C (2000) Solubilização de fostatos por microrganismos na presença de fontes de carbono. Pesq Agropec Bras. 24:311-319.

Soares MA, Li HY, Kowalski, KP, Bergen M, Torres MS, White, JF (2016) Functional role of bacteria from invasive Phragmites australis in promotion of host growth. Microb Ecol. 72:407-417.

Spaepen S, Vanderleyden J (2011) Auxin and plant-microbe interactions. Cold Spring Harb Perspect Biol. 3:1-13.

Statsoft I. (2014). Statsoft I: Statistica (data analysis software system). Version 7.

Tamura K, Peterson D, Peterson N, Stecher G, Nei M, Kumar $S$ (2011) MEGA5: Molecular evolutionary genetics analysis using maximum likelihood, evolutionary distance, and maximum parsimony methods. Mol Biol Evol. 28:2731-2739.

Tchuisseu Tchakounté GV, Berger B, Patz S, Fankem H, Ruppel S (2018) Community structure and plant growthpromoting potential of cultivable bacteria isolated from
Cameroon soil. Microbiol Res. 214:47-59.

Tian B, Zhang C, Ye Y, Wen J, Wu Y, Wang H, Li H, Cai S, Cai W, Cheng Z, Lei S, Ma R, Lu C, Cao Y, Xu X, Zhang, K (2017) Beneficial traits of bacterial endophytes belonging to the core communities of the tomato root microbiome. Agric Ecosyst Environ. 247:149-156.

Vieira FCS, Nahas E (2005) Comparison of microbial numbers in soils by using various culture media and temperatures. Microbiol Res. 160:197-202.

Waghmare PR, Patil SM, Jadhav SL, Jeon BH, Govindwar SP (2018) Utilization of agricultural waste biomass by cellulolytic isolate Enterobacter sp. SUK-Bio. ANRES. 52:399-406.

Ying W, Yang CD, Yao Yl, Wang YQ, Zhang ZF, Li XUE (2016) The diversity and potential function of endophytic bacteria isolated from Kobreasia capillifolia at alpine grasslands on the Tibetan Plateau, China. J Integr Agr. 15:2153-2162.

Wollum A (1982) Cultural methods for soil microorganisms. In: Miller DRAL, Keeney RH (ed.) Methods of soil analysis. 2ed.

Wu X, Rogers Leonard B, Zhu YC, Abel CA, Head GP, Huang F (2009) Susceptibility of Cry1Ab-resistant and -susceptible sugarcane borer (Lepidoptera: Crambidae) to four Bacillus thuringiensis toxins. J Invertebr Pathol. 100:29-34.

Yoorin (2018) Fornecendo nutrientes para aumentar sua produtividade.

http://www.yoorin.com.br/pt/produtos/ekosil

Zamil SS, Ahmad S, Choi MH, Yoon SC (2010) Production of poly-N-acetylglucosamine by Staphylococcus saprophyticus BMSZ711: Characterization and production optimization. Bioresour Technol. 101:7177-7180.

Zhang C, Kong F (2014) Isolation and identification of potassium-solubilizing bacteria from tobacco rhizospheric soil and their effect on tobacco plants. Appl Soil Ecol. 82:18-25.

Zhou D, Huang XF, Chaparro JM, Badri DV, Manter DK, Vivanco JM, Guo J (2016) Root and bacterial secretions regulate the interaction between plants and PGPR leading to distinct plant growth promotion effects. Plant Soil. 401:259-272. 